\title{
病態生理よりみた吻合部潰瘍に対する手術術式の選択に関する検討
}

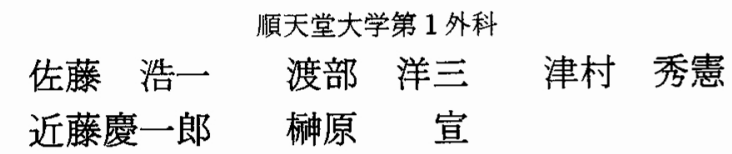

\section{SURGICAL TREATMENTS OF ANASTOMOTIC ULCERS BASED ON THEIR PATHOPHYSIOLOGY}

\author{
Koichi SATO, Yozo WATANABE, Hidenori TSUMURA, \\ Keiichiro KONDO and Noburu SAKAKIBARA
}

The First Department of Surgery, Juntendo University School of Medicine

吻合部潰煌27例を functioning parietal cell mass (FPCM) 残存16例, 胃切除断端幽門粘膜残存 4 例, 空置幽門粘膜 5 例, 不完全迷切 2 例に分けて検討した。基礎酸分泌量は空置幽門粘膜, 不完全迷 切で2.8，3.6mEq $/ \mathrm{hr}$, 最高酸分泌量は FPCM 残存, 空置幽門粘膜, 不完全迷切で13.7, $12.1,16.2$ $\mathrm{mEq} / \mathrm{hr}$ と高値を示した。また basal gastrin は空置幽門粘膜で $161.4 \mathrm{pg} / \mathrm{ml}$, insulin 刺激時の血清 gastrin 反応は空置幽門粘膜, 不完全迷切で $0.80,0.63 \mathrm{ng} \cdot \mathrm{min} / \mathrm{ml}$ と高值を示した。成因拉よび胃内 外分泌成績より FPCM 残存には迷切が, 幽門粘膜残存には残胃胃切または迷切が, 空置幽門粘膜には 空置幽門洞切除十迷切が，不完全迷切には再迷切が適切であることがわかった。

索引用語：吻合部潰瘍

\section{I. 緒 言}

吻合部潰瘍は胃切除術, あるいは胃空腸吻合術後に 発生する消化性潰瘍で，いわゆる医原性疾患であり， 治療にあたってはその病態を把握して確実に治癒せし めなければならない，吻合部漬瘍に対する治療法は, 保存的療法と外科的療法に大別されるが，吻合部潰瘍 の多くはその深達度がいわゆる ulIV と深いすのが多 〈1)2, 非常に難治性で, 保存的治療の治癒率は 6 $\sim 30.6 \%{ }^{3) \sim 6)}$ と低率であり，また出血 ${ }^{7) ~ 99}$ や穿孔(9910)な どの合併症の頻度が高率なため外科的治療法を必要と する場合が多い，以上のような理由で，吻合部潰凘に 対して外科的治療が繁用されているが，その治療成績 はかならずしも満足のいくものではなく, 吻合部潰湟 の再発率(7.8 20.4\% $\%^{7111) 16)}$ と高率である.

本研究の目的は, 吻合部潰瘍の成因を病態生理の面 より明確にし，それに基づいて適切な手術術式を決定 し, 吻合部潰瘍の再発を予防することにある。

$<1988$ 年 6 月 8 日受理 $>$ 別刷請求先 : 佐藤 浩一 T113 文京区本郷 2-1-1 順天堂大学医学部第 1 外科

\section{II. 研究対象と研究方法}

1. 研究対象

1972年 1 月より1986年12月までの 15 年間に当科で経 験した術後消化性潰瘍は40例で, 選択的迷走神経切離 術兼幽門形成術後の再発 5 例を除く, 胃切除後吻合部 潰煌は35例である。このうち释合糸によるもの，扰よ び成因の不明瞭なもの 8 例を除く 27 例を研究対象とし た.

2. 研究方法

（1）吻合部潰瘍の成因の検索方法

吻合部潰瘍27例の成因を検討するため，以下の検査 を施行した。

(1) 胃内外分泌機能検査

胃外分泌機能検査としては，基礎酸分泌量（basal acid output: BAO; $\mathrm{mEq} / \mathrm{hr}$ ) および histalog $2 \mathrm{mg} /$ $\mathrm{kg}$ 刺激時の胃酸分泌量 (maximal acid output: $\mathrm{MAO} ; \mathrm{mEq} / \mathrm{hr}$ ) を測定した. 手術術式として迷走神 経切離術(以下迷切) が施行されている症例には, Hollander test ${ }^{17)}$ を行い, Ross \& Kay の基準 ${ }^{18)}$ に従 い, 迷切が完全であるかどうかを判定した. 胃内分必 機能検查としては, 空腹時血清 gastrin 值 (basal gas- 
trin: $B G ; p g / m l)$, 肉汁ェキス刺激時の血清 gastrin 反応 (test meal stimulation-integrated gastrin response : T-IGR; $\mathrm{ng} \cdot \mathrm{min} / \mathrm{ml})$ おょ び insulin $0.2 \mathrm{u} /$ $\mathrm{kg}$ 低血糖刺激時の血清 gastrin 反応 (insulin hypoglycemia stimulation-IGR : I-IGR; $\mathrm{ng} \cdot \mathrm{min} / \mathrm{ml})$ を測 定した。また Zollinger-Ellison 症候群を鑑別するた め, secretin $2 \mathrm{u} / \mathrm{kg}$ 抢よび calcium $2 \mathrm{mg} / \mathrm{kg}$ 刺激時の 血清 gastrin 反応 (secretin stimulation-IGR: S-IGR 拉よび calcium stimulation-IGR: C-IGR; $\mathrm{ng} \cdot \mathrm{min} /$ ml）を測定した。なお IGR は各種刺激試験後で，BG より高値を示した各分画の 1 時間の総和で表した。

\section{(2) 胃 $\mathrm{X}$ 線検査}

胃 $\mathrm{X}$ 線検查により吻合部潰瘍の獄断を行うととも に，残胃の大きさについて検討した。

(3) 胃内視鏡検查

胃内視鏡検查により吻合部潰瘍の診断をより明確に するとともに, 吻合部残系の有無, congo red 散布法 ${ }^{19}$ や生検標本の病理組織学的検査による胃切除断端の幽 門粘膜の残存の有無, および空置幽門粘膜の存在を検 索した。

(4) 手術所見

手術所見は吻合部潰惶の成因の確認や検索を行ら上 で非常に有用である，胃切除例では残胃の大きさ，す なわち広範囲胃切除術（以下広範胃切）になっている かどうか， Billroth II 法吻合例では，十二指腸断端に 幽門洞が残在していないかどうか，輸入脚は長くない かどうか, 迷切例では前枝, 後枝の切離は完全である かどうか，また術前に血清 gastrin が高値を示す症例 では膵腫場が存在しないかどらかなどをみた。

（2）吻合部潰陽の分類

上記の検查成績および手術所見より，吻合部潰瘍の 成因を次のように分類した。

(1) Functioning parietal cell mass (FPCM) の残 存

(2) 胃切除断端幽門粘膜残存

(3) 空置幽門粘膜

(4) 不完全迷走神経切離術

（3）吻合部潰瘍の手術術式と治療成績

吻合部潰瘍の手術術式として, FPCM 残存による吻 合部潰晹 (以下 FPCM 残存) には迷切を, 胃切除断端 幽門粘膜残存による吻合部潰瘍（以下幽門粘膜残存） には残胃再切除術（以下残胃胃切）または迷切を，空 置幽門粘膜による吻合部潰瘍 (以下空置幽門粘膜)に は空置幽門切除(以下空置幽切) +迷切を, 不完全迷走
神経切離術による吻合部潰瘍（以下不完全迷切）には 再迷切を施行し，それぞれの治療成績および術後胃外 分泌機能について検討した。さらに上記の手術術式が 施行されなかった症例に対して，その治療成績を検討 した。

(4) 統計処理法

得られたデータは平均值士SEで表し，統計㚭理は すべて $\mathrm{t}$ 検定により行い，危険率が 0.05 以下の場合を 有意差ありとした。

\section{III. 成 績}

1. 成因による分類（表 1 )

(1) FPCM 残存

FPCM 残存は27例中16例 $(59.2 \%)$ と最も多く認め られた.

（2）幽門粘膜残存

幽門粘膜残存は27例中 4 例 (14.8\%) に認められた。 胃 $\mathrm{X}$ 線検査および手術時の検索では, 全例残胃が大き かった。

\section{(3) 空置幽門粘膜}

空置幽門粘膜は27例中 5 例 (18.5\%) に認められた。 内視鏡検查および手術時の検索により, 全例空置幽門 洞が確認された。

(4) 不完全迷切

不完全迷切は27例中 2 例 (7.4\%) に認められた。 Ross \& Kay の判定基準によると， 1 例は early positive, 他の 1 例は late positive であった.

2. 吻合部漬慯の胃内外分泌機能検查成績

\section{（1）胃外分泌機能検查成績}

$\mathrm{BAO}$ は FPCM 残存で $1.3 \pm 0.48 \mathrm{mEq} / \mathrm{hr}$, 幽門粘膜 残存で $0.25 \pm 0.18 \mathrm{mEq} / \mathrm{hr}$, 空置幽門粘膜で $2.8 \pm 0.57$ $\mathrm{mEq} / \mathrm{hr}$, 不完全迷切で $3.6 \pm 0.46 \mathrm{mEq} / \mathrm{hr}$ 之, 空置幽 門粘膜と不完全迷切で高値を示し，とくに不完全迷切 では FPCM 残存と比較して，有意に高值を示した。 MAO は FPCM 残存で $13.7 \pm 3.0 \mathrm{mEq} / \mathrm{hr}$, 幽門粘膜残

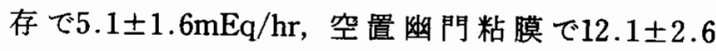
$\mathrm{mEq} / \mathrm{hr}$, 不完全迷切で $16.2 \pm 4.2 \mathrm{mEq} / \mathrm{hr}$ と, FPCM 残存, 空置幽門粘膜拉よび不完全迷切で高值を示し,

\section{表 1 胃切除後吻合部潰場27例の成因（1972.1} 1986. 12 順天堂大学第 1 外科)

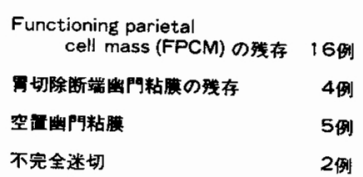


表 2 吻合部潰湯の術前胃外分泌機能検查成績

\begin{tabular}{|c|c|c|c|}
\hline & $\underset{(\mathrm{mEq} / \mathrm{hr})}{\mathrm{BAO}}$ & $\begin{array}{c}\mathrm{MAO} \\
(\mathrm{mEq} / \mathrm{hr})\end{array}$ & BAO/MAO比 \\
\hline F P CM残存 & $-1.3 \pm 0.48$ & $\Gamma^{13.7 \pm 3.0}$ & $Г \digamma 0.09 \pm 0.03$ \\
\hline 幽門粘膜残存 & $0.25 \pm 0.18$ & L s.1 $1 \pm 1.6$ & $--0.03 \pm 0.02$ \\
\hline 空置門粘膜 & $2.8 \pm 0.57$ & $12.1 \pm 2.6$ & ${ }^{\circ} L_{0.28 \pm 0.05}$ \\
\hline 不完全迷切 & $L_{3.6 \pm 0.46}$ & $16.2 \pm 4.2$ & $L-0.24 \pm 0.03$ \\
\hline
\end{tabular}

表 3 吻合部漬瘍の術前胃内分泌機能検査成績

\begin{tabular}{|c|c|c|c|}
\hline & $\begin{array}{c}\text { basal gastrin } \\
(\mathrm{pg} / \mathrm{ml})\end{array}$ & $\begin{array}{c}\text { T-IGR } \\
(\mathrm{ng} \cdot \mathrm{min} / \mathrm{ml})\end{array}$ & $\begin{array}{c}I-I G R \\
(n g \cdot \min / m I)\end{array}$ \\
\hline FPCM残存 & $-60.8 \pm 8.4$ & $0.46 \pm 0.22$ & $0.33 \pm 0.13$ \\
\hline 幽門粘膜残存 & $-51.6 \pm 8.8$ & $0.43 \pm 0.07$ & $0.07 \pm 0.05$ \\
\hline 空置幽門粘膜 & $L_{161.4 \pm 33.7}$ & $0.56 \pm 0.02$ & $0.80 \pm 0.41$ \\
\hline 不完全迷切 & $113.8 \pm 12.4$ & $0.31 \pm 0.16$ & $0.63 \pm 0.03$ \\
\hline
\end{tabular}

とくに FPCM 残存では幽門粘膜残存と比較して, 有 意に高値を示した. $\mathrm{BAO} / \mathrm{MAO}$ 比は, 空置幽門粘膜で $0.28 \pm 0.05$, 不完全迷切で $0.24 \pm 0.03$ と高值を示し, 他の 2 群との間に有意差が認められた（表 2 ）。

（2）胃内分泌機能検査成績

BG は FPCM 残存で $60.8 \pm 8.4 \mathrm{pg} / \mathrm{ml}$, 幽門粘膜残 存で $51.6 \pm 8.8 \mathrm{pg} / \mathrm{ml}$, 空置幽門粘膜で $161.4 \pm 33.7 \mathrm{pg} /$ $\mathrm{ml}$, 不完全迷切で $113.8 \pm 12.4 \mathrm{pg} / \mathrm{ml}$ 之, 空置幽門粘膜 で高值を示し, FPCM 残存および幽門粘膜残存との間 に有意差が認められた。

T-IGR は, 各群でほぼ同じような値を示した. I-IGR は FPCM 残存で $0.33 \pm 0.13 \mathrm{ng} \cdot \mathrm{min} / \mathrm{ml}$, 幽阴粘膜残 存で $0.07 \pm 0.05 \mathrm{ng} \cdot \mathrm{min} / \mathrm{ml}$, 空置幽門粘膜で $0.80 \pm$ $0.41 \mathrm{ng} \cdot \mathrm{min} / \mathrm{ml}$, 不完全迷切で0.63土0.03ng・ $\mathrm{min} / \mathrm{ml}$ と, 空置幽門粘膜および不完全迷切で高値を示したが, 他の 2 群との間に有意差は認められなかった（表 3 ）。

\section{3. 治療成績}

\section{(1) FPCM 残存}

FPCM 残存の初回手術術式は，広範胃切13例，幽門 洞切除術 3 例であった. 再手術として, 当科において 迷切のみが 7 例に, 迷切十残胃胃切が 6 例に施行され, 全例治瘾した. 残胃胃切のみが施行された 3 例のらち, 他院で施行された 1 例に再々発が認められ, 当科に入 院後, 迷切が施行され治癒した（表 4 ）.

(2) 幽門粘膜残存
表 4 FPCM 残存による吻合部漬瘍症例

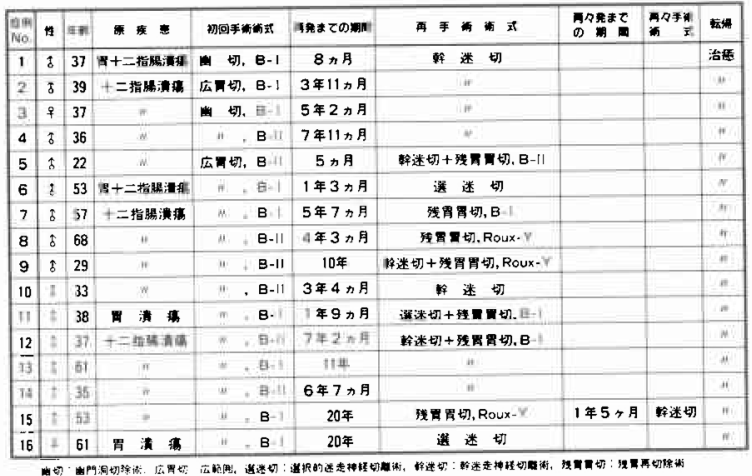

表 5 幽門粘膜残存による吻合部潰場症例

\begin{tabular}{|c|c|c|c|c|c|c|c|}
\hline 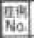 & 19 & If & 原慧 & 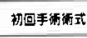 & 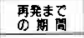 & 再手河涌式 & 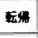 \\
\hline 1 & $\hat{\delta}$ & 34 & 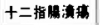 & 広田切。 B-1 & 11年1カ月 & 蜶迷切 & 治事 \\
\hline 2 & $\delta$ & 70 & 五 事 & i) $8-1$ & 2年 1 カ月 & 线用用切, 旦-11 & " \\
\hline 3 & B & 44 & 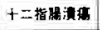 & $8-1$ & 23 年 & 线田的, B - 11 & it \\
\hline 4 & f & 54 & 角 & $B$ & 6年 3力月 & 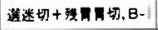 & $"$ \\
\hline
\end{tabular}

表 6 空置幽門粘膜による吻合部潰瘍症例

\begin{tabular}{|c|c|c|c|c|c|c|c|c|c|}
\hline 霖 & 4 & कn & 原事 & 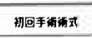 & 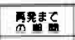 & 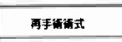 & 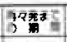 & 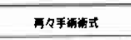 & $\min$ \\
\hline 1 & 8 & 41 & 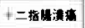 & 広音切, B-11 & $8 n$ 月 & 转用解, Roux-Y & $1 \%$ & 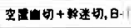 & 洁筆 \\
\hline 2 & $:$ & 60 & " & A & 3 年10 月 & 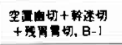 & & & . \\
\hline 3 & 7 & 18 & a & " & $9 n$ 月 & 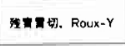 & 2 - तh & 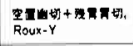 & y \\
\hline 4 & 7 & 50 & $*$ & $"$ & 3年 $8=$ 月 & 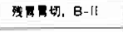 & 4年3月月 & 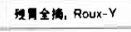 & " \\
\hline 5 & ? & 45 & 4) & $\omega$ & 5年11》月 & 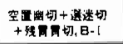 & & & $"$ \\
\hline
\end{tabular}

幽門粘膜残存の初回手術術式は, 全例広範胃切で あった。再手術として当科において，残胃胃切のみが 2 例に, 迷切のみが 1 例に, 迷切十残胃胃切が 1 例に 施行され，全例治癒した（表 5 ).

（3）空置幽門粘膜

空置幽門粘膜の初回手術術式は, 全例広範胃切で あった，再手術として当科において，空置幽切十残胃 胃切が 2 例に施行され，治癒した．しかし残胃胃切の みが当科に打いて 1 例，他院に拈いて 2 例施行され， 全例再々発した。これらの再々発例に対して, 当科に 扣いて空置幽切十迷切が 1 例に, 空置幽切十残胃胃切 が 1 例に, 残胃全摘が 1 例に施行され, 全例治癒した. ここで残胃全摘が施行された 1 例は，手術所見で脺腫 瘤を認めたため, Zollinger-Ellison 症候群の可能性が 否定できず，脺体尾部合併切除を施行したものであっ た（表6）.

(4) 不完全迷切 
表 7 不完全迷切による昒合部潰崵症例

\begin{tabular}{|c|c|c|c|c|c|c|c|c|c|c|c|}
\hline \begin{tabular}{|l} 
定挒 \\
Na. \\
\end{tabular} & 性 & 年卙 & 原患 & 初回手術術式 & $\begin{array}{l}\text { 垔無まて } \\
\text { の期間 }\end{array}$ & 再手政政式 & 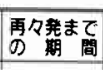 & 再々手術術式 & 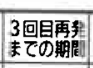 & 3回目手柬衡 & 5 \\
\hline 1 & q & 42 & 十二指腸潰涯 & 選迷切+幽切，B-1 & 3年10力月 & 幹迷切十残胃胃切，B-1 & & & & & 治思 \\
\hline 2 & $\hat{o}$ & 50 & " & 幹迷切十胃空勝吻合 & 24年 8カ月 & 広胃切，B-1 & 1年6力月 & 残胃胃切.B-I & 1年8ヶ月 & 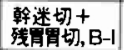 & 治急 \\
\hline
\end{tabular}

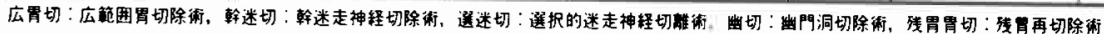

表 8 吻合部潰瘍の術後胃外分泌機能検査成績

\begin{tabular}{|c|c|c|}
\hline & $B A O(m E q / h r)$ & $\mathrm{MAO}(\mathrm{mE} / \mathrm{hrc})$ \\
\hline 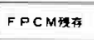 & $0.13 \pm 0.12$ & $1.60 \pm 0.92$ \\
\hline 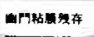 & 0 & 0 \\
\hline 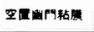 & $0.13 \pm 0.11$ & $0.43 \pm 0.27$ \\
\hline 不完全迷切 & 0 & 0 \\
\hline
\end{tabular}

不完全迷切による吻合部潰瘍の初回手術術式は，選 択的迷走神経切離術兼幽門洞切除術(以下選迷切十幽 切）が 1 例，迷切＋胃空腸吻合が 1 例であった。再手 術として，選迷切十幽切に対しては当科において，再 迷切十残胃胃切が施行され治癒した。迷切十胃空腸吻 合に対しては, 他院において厇範胃切が施行されたが, 再々発した。再々手術として, やはり他院に批いて残 胃胃切が施行されたが， 3 回目の再発をしたため，当 科に入院となった。最終的に, 当科に扔いて, 再迷切十 残胃胃切が施行され治癒した（表 7).

\section{4. 術後胃外分泌機能検査成績}

BAO は FPCM 残存で $0.13 \pm 0.12 \mathrm{mEq} / \mathrm{hr}$, 幽門粘 膜残存で $0 \mathrm{mEq} / \mathrm{hr}$, 空置幽門粘膜で $0.13 \pm 0.11 \mathrm{mEq} /$ $\mathrm{hr}$, 不完全迷切で $\mathrm{OmEq} / \mathrm{hr}$ と良好な減酸を示した。

$\mathrm{MAO}$ む $\mathrm{FPCM}$ 残存で $1.60 \pm 0.92 \mathrm{mEq} / \mathrm{hr}$, 幽門粘膜 残存で $0 \mathrm{mEq} / \mathrm{hr}$, 空置幽門粘膜で $0.43 \pm 0.27 \mathrm{mEq} / \mathrm{hr}$, 不完全迷切で $0 \mathrm{mEq} / \mathrm{hr}$ と良好な減酸を示した。これら の症例を術後 2 年から 15 年をで経過観察を行っている が, 現在まで再発を認めていない(表 8).

\section{IV. 考察}

吻合部潰晹は医原性疾患であり，高率に再発するた め, 治療にあたってはその成因を詳細に検討し，治療 方針を決定することが重要である．著者らは成因を検 討するにあたり, 胃内外分泌機能検查, 胃 X 線検査, 胃内視鏡検査および手術所見の検討を行い，成因が不 明瞭なものが 5 例あったものの，吻合部潰湟の成因を ある程度正確に把握することができたと思われる，三 隅ら ${ }^{20)}$ は吻合部潰瘍の成因の分析には, X 線検查, 内 視鏡検査および手術所見により，残胃の大ささを判定 し, BG, BAO/MAO 比, I-IGR などの胃内外分泌機能
検查成績や残胃吻合部の生検により幽門粘膜残存の有 無を検索している。

FPCM 残存による吻合部潰瘍は原疾患, 手術術式お よび胃液検査成績により容易に推察できる、近藤 ${ }^{21}$ は $\mathrm{MAO}$ が $20 \mathrm{mEq} / \mathrm{hr}$ 以上の hypersecretor は十二指腸 潰瘍にしろ，胃潰瘍にしろ迷走神経優位であり， FPCM が多いと述べている.したがって原疾患がこの ような症例で，幽門粘膜の残存むなく，迷切も行われ ておらず，かつ吻合部潰瘍の MAO が $10 \mathrm{mEq} / \mathrm{hr}$ 以上 の症例は, FPCM 残存が原因と考えられる。竹村ら 22 はさらに，内視鏡下の残胃の生検により，壁細胞活性 の程度がわかり, tetragastrin 静注後の congo red 胃 内散布や術中に ph meter を用いる方法により壁細胞 の機能を判定できると述べている.

空置幽門粘膜の検索には，胃内外分泌機能検査成績 が有効である，すなわち，原疾患が十二指腸潰瘍で, かつ Billroth II 法吻合に上る胃切除後で, BAO, $\mathrm{BAO} / \mathrm{MAO}$ 比， BG および I-IGR が高值を示す症例 は, 空置幽門粘膜による吻合部潰瘍を強く疑う必要が ある ${ }^{23)}$.こうした症例に対しては, 内視鏡による十二指 腸断端粘膜の生検法により診断を確定するが，生検が 不可能な場合には, ${ }^{99 \mathrm{~m}} \mathrm{Tc}$-pertechnetate 用いた antral scanning ${ }^{24)}$ が有効である. Lee ら ${ }^{25}$ は術後の病 理組織学的検查で確定診断された空置幽門粘膜22例に 対して，術 前に ${ }^{99 m} \mathrm{Tc}$-pertechnetate 用い, 16例 (72.7\%) に空置幽門粘膜の存在を証明しており, 1.5 $\mathrm{cm}$ の大ささまで診断可能であると報告している.

不完全迷切の証明には, Hollander test が広く用い られているが, Cleater ら ${ }^{26)}$ は22例の吻合部潰瘍中11 例が Hollander test 陽性であったと報告している．著 者らの成績でも, 迷切 2 例中 1 例が early positive, 1 例が late positiveであった.

吻合部潰瘍の成因は，残胃が大きいこと，すなわち 胃切除範囲の不足によるとする報告が多く，この中に は FPCM 残存による吻合部潰瘍が多く含まれている と考えられる. 三隅ら ${ }^{201}$ は吻合部潰煬42例中こうした 成因のものは28例 $(66.7 \%)$, 関根ら ${ }^{27}$ も11例中 7 例 


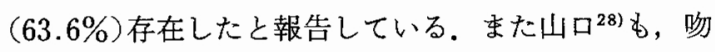
合部潰瘍 7 例の成因は, 初回手術時の胃切除範囲が狭 く，切りたりないことであるとしており，再胃切除の 際, 小弯側は2.5 6.0 cm, 大弯側は $5.0 \sim 11.0 \mathrm{~cm}$ 切除 しなければならなかったと述べている。

FPCM 残存による吻合部潰演の成因は, 壁細胞自体 の機能的異常によるものであるが，吉田ら ${ }^{29}$ は幽門腺 が存在しない吻合部潰瘍の成因は, parietal cell mass の量的ならびに分泌機能異常であると述べている。ま

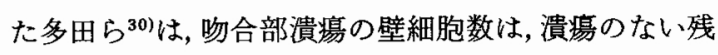
胃に比べて有意に多いと述べている.小泉ら ${ }^{14)}$ は, 残胃 が小さく, 血清 gastrin も低值を示し, 再々発を括こし た吻合部潰瘍 4 例の胃酸分泌六進は胃壁細胞自体の著 明な過形成が原因であったと報告している.

胃切除断端に幽門粘膜が残存する症例は，当科では 27 例中 4 例 (14.8\%)であったが，杉山ら ${ }^{311}$ は 41 例中 32 例 $(78.0 \%)$ ，三隅ら ${ }^{20)}$ は24例中 16 例 $(66.7 \%)$ とかな り高率に幽門粘膜が残存すると報告している。著者ら の成績では，幽門粘膜残存による吻合部潰崵の胃内外 分泌は，上もに高値を示さなかったが，番場32)は残胃の 幽門腺区域が $2.0 \mathrm{~cm}$ を越えると有効な減酸効果が得 られないと述べており，また杉山ら ${ }^{311}$ は幽門粘膜の残 存面積が大きい注ど胃酸分泌と gastrin 分泌に充進が みられ，幽門腺の残存は再発と密接に関係していると 述べている.

空置幽門粘膜は，当科では27例中 5 例 $(18.5 \%) に$ みられ，三隅ら $201 の 16.7 \%$, 白鳥ら ${ }^{331}$ の $22.0 \%$ とほぼ同 じ成績であった。

不完全迷切によると吻合部潰瘍は, 当科に抋いては 27 例中 2 例 $(7.4 \%)$ と少なかったが, 欧米に扔いては より多くの報告がみられ, Green ら ${ }^{34)}$ は, 不完全迷切が 再発潰㕫の成因として最も多かったと述べている。不 完全迷切の症例では, 一般に後枝の残存する場合が多 く,Fawcett ${ }^{35}$ ) は後枝残存が46例に対して, 前枝残存が 18例, Venables ${ }^{36)}$ は後枝残存が 5 例に対して前枝残存

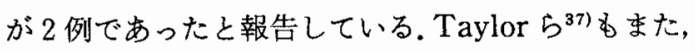
手術所見に怙いて，後枝残存は41例中 27 例 $(66.0 \%)$ であったのに対して，前枝残存は 8 例(19.5\%)であっ たと述べている。さらに彼は, 後枝残存例では Hollander test の Ross \& Kay の判定基準で, early positive が16例, late positive $か ゙ 4$ 例, negative $か ゙$ 例, 前枝 残存例では early positive が 3 例, late positive が 4 例, negative が 1 例と, 後枝残存例では前枝残存例に 比べて, early positive が有意に多かったと報告してお
り, 迷切の際の後枝切離の重要性を強調している.

吻合部潰瘍に対寸る手術術式として, 著者らは FPCM 残存に対して迷切, 幽門粘膜残存に対して残胃 胃切または迷切, 空置幽門粘膜に対しては空置幽切十 迷切，不完全迷切に対して再迷切を施行した。すなわ ち, FPCM 残存による吻合部潰㻛はその成因から考え て迷走神経優位であり，また MAO が高值を示すこと より, 手術術式として迷切を施行するのが適切である と考兄られる。幽門粘膜残存による吻合部潰瘍には残 存幽門粘膜を切除する目的で, 残胃胃切を施行するの が適切である、しかし原疾患が十二指腸潰漡の場合に は迷走神経優位のことが多く，残胃胃切を行わず迷切 を施行するのみでよい，空置幽門粘膜による吻合部潰 瘍は, 空置幽切が必要であり,これを施行しない限り は潰瘍再発を高率に繰り返す ${ }^{38)}$ 。 また原疾患のほとん ぞが十二指腸潰瘍で, MAO が高值を示すことより, 迷 切を併せ行った洼らがよい，不完全迷切による吻合部 潰瘍は, 再迷切を施行し, 迷切を完全にすることが重 要である.ただし上記のうち, 迷切のみの術式です, 潰湢が深く, 他葴器に穿通していたり, 瘦孔を形成し たりしている症例や，吻合口が小さくて迷切により胃 内容停滞の危険がある症例に対しては, 残胃胃切を付 加する必要があると思われる。

以上の上うに, 成因を明確にし, 病態生理的特徵を 把握した上で，手術術式を選択寸ることにより，好成 績が得られると考兄られる。三隅ら ${ }^{201}$ は, 吻合部潰瘍の 手術術式の選択注つて, 残胃が大きいか, 残胃大弯 側に幽門粘膜が残存していれば再胃切を, 空置幽門粘 膜の場合は空置幽切または空置幽門粘膜のみの抜去を 行らのがよいと述べている。 また残胃が小さく，幽門 粘膜が残存せず，高 gastrin 血症を示さず，BAO およ び insulin 刺激時の胃酸分泌量が高値を示す症例には 迷切単独でよく, 原疾患が十二指腸漬瘍で, 高酸, 高 gastrin 血症を示し, BAO, BAO/MAO 比が高值を示 寸症例には，残胃胃切十迷切が必要であると述べてい る. 迷切後の再発例に対しては Hollander test や手術 中の検索を行い，不完全迷切とわかれば，再迷切が必 要である.

吻合部潰煌の術後胃外分泌機能検查成績は，各群に おいて, BAO, MAO とも非常に良好な減酸率を示し た. 大久保ら ${ }^{399}$ は $\mathrm{MAO} か 2.5 \mathrm{mEq} / \mathrm{hr}$ 以下なら再発の 可能性はないとしているが，著者らの成績でも MAO は, FPCM 残存の術後で $1.60 \mathrm{mEq} / \mathrm{hr}$ を示したのが最 高で, 他の群はこれ以下であった. 


\section{V. 結 語}

当科で経験した吻合部潰瘍 27 例について, 病態生理 の面より手術術式を選択し，術後成績を検討し，以下 の結論を得た。

1. 吻合部潰瘍 27 例の成因を, 胃内外分泌機能検査, 胃 $\mathrm{X}$ 線検查, 胃内視鏡検査㔚よび手術所見により, FPCM 残存16例, 幽門粘膜残存 4 例, 空置幽門粘膜 5 例，不完全迷切 2 例に分類することができた。

2. 胃外分泌機能検查成績では, BAO は空置幽門粘

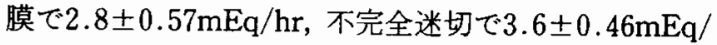
$\mathrm{hr}$ と高値を示した. MAO は FPCM 残存で $13.7 \pm 3.0$ $\mathrm{mEq} / \mathrm{hr}$ ，不完全迷切で $16.2 \pm 4.2 \mathrm{mEq} / \mathrm{hr}$ 之高値を示 した。また $\mathrm{BAO} / \mathrm{MAO}$ 比は空置幽門粘膜で $0.28 \pm$ 0.05 , 不完全迷切で $0.24 \pm 0.03$ と高値を示した.

3. 胃内分泌機能検査成績では, BG は空置幽門粘膜 で161.4土33.7pg/ml と高値を示した。また I-IGR は 空置幽門粘膜で $0.80 \pm 0.41 \mathrm{ng} \cdot \mathrm{min} / \mathrm{ml}$, 不完全迷切で $0.63 \pm 0.03 \mathrm{ng} \cdot \mathrm{min} / \mathrm{ml}$ と高値を示した。

4. 成因拉よび胃内外分泌機能検査成績上り, FPCM 残存には迷切が，幽門粘膜残存には残胃胃切ま たは迷切が，空置幽門粘膜には空置幽切十迷切が，不 完全迷切には再迷切が適切であることがわかった。

5. 術後成績では, 吻合部潰湟の再発はみられず,

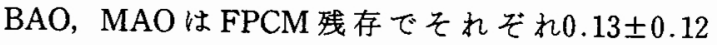
$\mathrm{mEq} / \mathrm{hr}, 1.60 \pm 0.92 \mathrm{mEq} / \mathrm{hr}$, 幽門粘膜残存で $0 \mathrm{mEq} /$ $\mathrm{hr}, 0 \mathrm{mEq} / \mathrm{hr}$, 空置幽門粘膜で $0.13 \pm 0.11 \mathrm{mEq} / \mathrm{hr}$, $0.43 \pm 0.27 \mathrm{mEq} / \mathrm{hr}$, 不完全迷切で $0 \mathrm{mEq} / \mathrm{hr}, 0 \mathrm{mEq} / \mathrm{hr}$ と非常に良好な减酸を示した。

以上の結果より，吻合部潰陽の手術術式を決定する 際には，その成因を十分に検討し，病態生理に適した 術式を選択することが重要であることがわかった。

本論文の要旨は，第 49 回日本臨床外科医学会総会 (福岡) において発表した。

\section{文 献}

1) 浅見恵司, 島津久明, 木下智治注か: 術後再発潰瘍 の症例. 手術 $22: 1-2,1968$

2）遠城寺宗知, 古賀 淳：胃腸吻合部の良性病変 一吻合部潰煌と吻合部ポリープー，胃と腸 12 ： 893-902，1977

3）青木照明：吻合部潰場の外科的治療について。臨 外 $27: 1747-1753,1972$

4）鈴木博孝, 朝戸末男, 押淵英晃ほか: 残胃の良性病 変一主として吻合部潰煌について一。胃と腸 12 : 883-892, 1977

5) Stage JG, Hernriksen FW, Kehlet $\mathrm{H}$ : Cimetidine treatment of recurrent ulcer. Scand
J Gastroenterol $14: 977-979,1979$

6）塚本秀人, 比企能樹, 高橋俊毅㳗か：吻合部潰瑒手 術例の検討。日消外会誌 $18: 631-639,1985$

7）中山康夫, 禀川公章, 香川修司ほか：消化性潰㷎手 術後の潰煬再発例について。 日臨外医会誌 45 ： 1282-1290，1984

8）白鳥常男，島野吉裕，金岡敏彦添加：伆合部潰煬. 臨外 31:1027-1034，1976

9) Condon JR, Tanner NC: Retrospective review of 208 proved cases of anastomotic ulcer. Gut $9: 438-441,1968$

10) Jaffe BM, Newton WT, Judd DR et al : Surgical management of recurrent peptic ulcers. Am J Surg 117 : 214-221, 1969

11) Hoffmann J, Shokouh-Amiri MH, Klarskov $P$ et al: Gastrectomy for recurrent ulcer after vagotomy: Five to nineteen year follow up. Surgery $99: 517-522,1986$

12) Heppell J, Bess MA, McIlrath DC et al : Surgical treatment of recurrent peptic ulcer disease. Ann Surg $198: 1-4,1983$

13) Kennedy $T$, GreenWER: Stomal and recur. rent ulceration: Medical or surgical management?. Am J Surg 139:18-21, 1980

14）小泉 裕, 河井啓三, 岡部紀正注か：吻合部潰湯症 例の検討。日消外会誌 $11: 290-296,1978$

15) Boles RS, Marshall SF, Bersoux RV: Follow up study of 127 patients with stomal ulcer. Gastroenterology $38: 763-768,1960$

16) Schirmer BD, Myers WC, Hanks JB et al: Marginakl ulcer. A difficult surgical problem. Ann Surg 195 : 653-661, 1982

17) Hollander F: Laboratory procedures in the study of vagotomy. Gastroenterology 11 : 419-425, 1948

18) Ross BM, Kay AW: The insulin test after vagotomy. Gastroenteology $46: 379-386,1964$

19）城所 仂，渡部洋三：迷走神経切離術兼幽門洞切 除術。外科 Mook 1:133-146, 1978

20）三隅厚信，平田武臣，八木泰志汪か：物合部溃場. 臨と研 $55: 404-412,1978$

21）近藤慶一郎：胃内外分泌機能ならびに幽門洞部の 形態学的変化よりみた消化性潰瘍の病㮩生理学的 研究. 日消病会誌 $76: 1929-1941 ， 1979$

22）竹村 浩, 杉山 貢, 土屋周二：難治性吻合部潰 場. この症例に対する手術適応之術式の選択. 外科 $44: 887-892,1982$

23）佐藤浩一，渡部洋三，津村秀憲潘か：空置幽門粘膜 残存による吻合部潰瘍の病態生理に関する検討。 日消外会誌 $21: 11-19,1988$

24) Lee $\mathrm{CH}$, P'eng FK, Lui WY: The clinical aspect of retained gastric antrum. Arch Surg 
$121: 1181-1186,1986$

25) Lee $\mathrm{CH}$, P'eng $\cdot \mathrm{FK}$, Yeh PHH : Sodium pertechnetate Tc $99 \mathrm{~m}$ antral scan in the diagnosis of retained gastric antrum. Arch Surg 119:309 $-311,1984$

26) Cleator IGM, Holubitsky IB, Harrison RC: Anastomotic ulceration. Ann Surg 179:339 $-351,1974$

27）関根 毅, 林 哲明, 佐々木蟋ほか：吻合部潰瘍の 検討一とくに胃酸分泌に視点を向けて一. 外科 $37: 31-37,1975$

28）山口吉康：残胃の大きさに関する問題一特に吻合 部潰瘍症例の残胃所見を中心として一. 手術 $22: 584-590,1968$

29）吉田 寿：伆合部潰瘍の検討. 日消外会誌 11 : $1439-1441,1972$

30）多田正弘, 榊 信広, 小田原満ほか：壁細胞からみ た吻合部潰泊の生検組織学的研究. Gastroenterol Endosc $21: 405-410,1979$

31）杉山 貢, 土周周二：胃・十二指腸溃湯一殊に再発 潰瘍の診断之治療一。外科治療 $37: 405-414$, 1977

32）番場道夫：消化珄潰瘍に対する“保存的”胃切除に 関する臨床的, 実験的研究. 第 II 編. 実験的研究,
特に切除残胃に扔ける残存幽門腺区域が，胃体腺 壁細胞に及ばす影響, 並びに幽門腺・胃体腺境界部 の術中, 推定法について. 日外会誌 $67: 253$ $-265,1966$

33）白鳥常男, 島野吉裕, 金岡敏彦：吻合部潰瘍. 臨外 $31: 1027-1034,1976$

34) Green WER, Kennedy $T$, Hassard $T$ et al : Management of recurrent peptic ulceration. $\mathrm{Br}$ J Surg $65: 422-426,1978$

35) Fawcett AN, Johnston D, Duthie HL: Revagotiomy for recurrent ulcer after vagotomy and drainage for duodenal ulcer. Br J Surg 56 : 111-116, 1969

36) Venables $\mathrm{CW}$ : The value of a combined pentagastrin insulin test in studies of stomal ulceration. Br J Surg 57 : 757-761, 1970

37) Taylor TV, Pearson KW, Torrance B : Revagotomy for recurrent peptic ulceration. $\mathrm{Br}$ J Surg 64:477-481，1977

38）渡部洋三：胃切除吻合部潰湯. 外科 $44: 893$ $-901,1982$

39）大久保高明, 杉山 賁, 杉田秀雄はか：十二指腸潰 腸に対する手術術式. 手術 $28 ： 725-734 ， 1974$ 